\title{
Effect of Adenosine Deaminase Inhibition upon Human
}

\section{Lymphocyte Blastogenesis}

\author{
Dennis A. Carson and J. Edwin Seegmiller \\ From the Department of Medicine, University of California, San Diego, \\ La Jolla, California 92037
}

\begin{abstract}
A B S T R A C T The biochemical mechanisms by which a genetically determined deficiency of adenosine deaminase leads to immunodeficiency are still poorly understood and prompted this study. We have examined the effects of the adenosine deaminase inhibitor erythro-9(2-hydroxy-3-nonyl) adenine hydrochloride (EHNA) upon the response of human peripheral blood mononuclear cells to the mitogen concanavalin A (Con A). Cells isolated from normal volunteers were incubated in microtiter plates in the presence of various inhibitors, and the incorporation of tritrated thymidine or leucine into macromolecular material was measured after $64 \mathrm{~h}$. EHNA at a concentration of $0.3 \mu \mathrm{M}$, which inhibited $90 \%$ of the adenosine deaminase (ADA) activity in a mononuclear preparation, impaired the incorporation of tritrated leucine into protein; $100 \mu \mathrm{M}$ EHNA was the minimal concentration that inhibited thymidine uptake. The addition of $15 \mu \mathrm{M}$ adenosine or $10 \mu \mathrm{M}$ cyclic AMP to Con A-stimulated lymphocytes inhibited leucine uptake, while millimolar concentrations were required to inhibit thymidine uptake. Lower doses of adenosine and cyclic AMP stimulated thymidine incorporation. The inhibition of thymidine uptake observed with millimolar concentrations of adenosine was independent of the type of mitogen (pokeweed or Con A), the concentration of mitogen, or the medium used, but could be increased if the cells were cultured in a serum with reduced levels of adenosine deaminase. Washout experiments failed to demonstrate a critical period early in immune induction during which adenosine exerted its inhibitory effects. Noninhibitory doses of EHNA potentiated the effects of adenosine and cyclic AMP on leucine and thymidine uptake. EHNA at a concentration of $50 \mu \mathrm{M}$ also
\end{abstract}

Dr. Carson is a postdoctoral fellow of the Arthritis Foundation.

Received for publication 10 June 1975 and in revised form 2 October 1975. potentiated the inhibitory effects on thymidine uptake of dibutyryl cyclic AMP, butyric acid, norepinephrine, and isoproterenol, but not theophylline. When mitogenesis was assayed by leucine incorporations, no synergy between EHNA and these compounds was apparent. Uridine relieved to some extent the inhibition of blastogenesis produced by adenosine and cyclic AMP, but not by dibutyryl cyclic AMP, norepinephrine, isoproterenol, or theophylline. Neither uridine alone nor uridine plus adenosine protected lymphocytes from the inhibitory effects of EHNA.

\section{INTRODUCTION}

Recently, several children with combined immunodeficiency disease have been found who lack the enzyme adenosine deaminase (1-4). Since both disorders are extremely rare, their concurrent appearance in at least 14 different families provides a convincing argument for a causal relationship of the enzyme defect to the appearance of the clinical disease. Several recent experiments have attempted to elucidate the function of adenosine deaminase during lymphocyte growth and differentiation.

The addition of exogenous adenosine, and in some cases of adenine nucleotides, has been shown to inhibit the phytohemagglutinin-induced blastogenesis of normal human lymphocytes $(5,6)$, the growth of human lymphoblast cell lines (7), and the in vitro destruction of human cells by specifically sensitized mouse lymphocytes (8). In the latter case, Wolberg and co-workers demonstrated that the sensitivity of lymphocytes to adenosine could be potentiated by the presence of an inhibitor of adenosine deaminase, erythro-9-(2-hydroxy3-nonyl) adenine hydrochloride (EHNA) ${ }^{2}$ (9).

${ }^{1}$ Abbreviations used in this paper: Con A, concanavalin A ; EHNA, erythro-9-(2-hydroxy-3-nonyl) adenine hydrochloride. 
Whether or not the immunodeficiency associated with adenosine deaminase deficiency is due to adenosine toxicity is at present unknown, since adenosine levels have not been measured in affected patients. Adenosine in high concentrations, however, can block the formation of phosphoribosyl pyrophosphate, necessary for de novo purine and pyrimidine biosynthesis,' and in some systems can also elevate intracellular cyclic AMP levels $(10,11)$. These consequences of adenosine accumulation would be expected to interfere with lymphocyte proliferation, but the relative importance of each, if any, is unknown.

In this report we examine the effects of the adenosine deaminase inhibitor EHNA upon human peripheral lymphocyte mitogenesis, and its ability to potentiate the effects of adenosine and cyclic AMP. The results indicate that inhibition of adenosine deaminase alone can significantly impair lymphocyte transformation, as well as sensitize the lymphocytes to the inhibitory effects of exogenous adenosine. The recent report of nucleoside phosphorylase deficiency in a patient with T-cell immunodeficiency (12) provides additional support for the view that metabolism of purine bases and nucleosides is critically important for the normal function of the immune system.

\section{METHODS}

Lymphocyte isolation. Blood from healthy laboratory volunteers was collected with heparin (The Upjohn Company, Kalamazoo, Mich.) as anticoagulant, and the erythrocytes were sedimented for $1 \mathrm{~h}$ at $37^{\circ} \mathrm{C}$ in the presence of $0.6 \%$ vol/vol Macrodex dextran (Pharmacia Fine Chemicals, Piscataway, N. J.). 5-ml portions of the leukocyte-rich plasma were layered over $2 \mathrm{ml}$ Ficoll-Hypaque (obtained as LSM solution from Litton Bionetics, Kensington, Md.) and centrifuged at $1,800 \mathrm{~g}$ for $10 \mathrm{~min}$ in $16 \times 100-\mathrm{cm}$ plastic tubes (Falcon 3030, Falcon Plastics, Div. of BioQuest, Oxnard, Calif.). The lymphocyte-containing interphase was recovered, washed twice in RPMI 1640 medium (Flow Laboratories, Inc., Rockville, Md.), and counted in a hemocytometer. Cell yield averaged $10 \% \mathrm{ml}$ of blood. When examined by light microscopy after Wright's staining, 95\% of the cells were mononuclear with variable platelet contamination.

Culture conditions. Lymphocytes were cultured in microplates (Falcon 3040) containing $2 \times 10^{5}$ cells in a final volume of $0.22 \mathrm{ml}$. Unless otherwise indicated, all cultures contained $10 \% \mathrm{AB}, \mathrm{Rh}$-positive human serum, obtained from pooled, outdated blood plasma, and either RPMI 1640 or Eagle's minimal essential medium supplemented with penicillin $(100 \mu \mathrm{g} / \mathrm{ml})$, streptomycin $(100 \mathrm{U} / \mathrm{ml})$, and glutamine $(2 \mathrm{mM})$. Unless otherwise indicated, the serum was heated for $1 \mathrm{~h}$ at $56^{\circ} \mathrm{C}$ before use, to denature adenosine deaminase partially. Mitogens were added at just below optimal concentrations, i.e., $25 \mu \mathrm{g} / \mathrm{ml}$ for concanavalin A (Con A) (Sigma Chemical Co., Inc., St. Louis, Mo.) and $5 \mu \mathrm{l} / \mathrm{ml}$ for pokeweed mitogen (Grand Island Biological Co., Grand Island, N. Y., prepared from a stock solution

${ }^{2}$ Snyder, F., and J. E. Seegmiller. Manuscript in preparation. diluted in medium as described by the manufacturers). In those experiments where lymphocytes were cultured in the absence of serum, Con $\mathrm{A}$ was used at a concentration of $1.5 \mu \mathrm{g} / \mathrm{ml}$. The plates were incubated in a humidified atmosphere containing $5 \%$ carbon dioxide and $95 \%$ air. Unless otherwise stated, Con A was the mitogen used in all experiments.

In some cases, where indicated, lymphocytes were cultured in $12 \times 75-\mathrm{mm}$ plastic tubes (Falcon 2058) in a volume of $1 \mathrm{ml}$. After varying periods, they were centrifuged at $80 \mathrm{~g}$ for $5 \mathrm{~min}$ and resuspended in fresh medium. Conditions were otherwise identical to those described above.

Measurement of thymidine incorporation into $D N A$. After $48 \mathrm{~h}$ in culture, $0.2 \mu \mathrm{Ci}$ of $\left[6-^{-3} \mathrm{H}\right]$ thymidine, sp act $2 \mathrm{Ci} / \mathrm{mM}$ (Amersham/Searle Corp., Arlington Heights, Ill.), was added to each well. $16 \mathrm{~h}$ later, the cells were collected on glass fiber filters with aid of a multiple automated sample harvester (Microbiological Associates, Bethesda, Md.) and washed with distilled water. The number of counts precipitated was identical whether or not $10 \%$ trichloracetic acid was used for washing. The filters were dried, suspended in a toluene-based scintillation fluid, and counted at an efficiency of $51 \%$ in a Beckman liquid scintillation counter (Beckman Instruments, Inc., Fullerton, Calif.). Cells cultured in human serum in the presence of Con A regularly incorporated more than 100 times as much tritiated thymidine as cells cultured in the absence of mitogen; for pokeweed mitogen this ratio varied from 50 to 100 , while in horse serum or serum-free medium cultured with Con A it averaged $15-30$.

Measurement of leucine incorporation into protein. In other experiments, $1.0 \mu \mathrm{Ci}$ of $\mathrm{L}-\left[4,5-{ }^{3} \mathrm{H}\right]$ leucine, sp act 1.0 $\mathrm{Ci} / \mathrm{mM}$ (Amersham/Searle), was added to each well after $60 \mathrm{~h}$ of culture, and the cells were harvested $4 \mathrm{~h}$ later, as described above, except that they were first washed with normal saline, and subsequently with $10 \%$ trichloracetic acid. The incorporation of tritiated leucine into protein in Con A-stimulated cultures averaged 15-50 times more than in control cultures.

Adenosine deaminase assay. Washed lymphocytes were suspended at a concentration of $10^{7}$ cells $/ \mathrm{ml}$ in a buffer con-

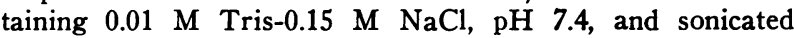
for $20 \mathrm{~s}$ at $4^{\circ} \mathrm{C}$ in a Biosonik (Will Scientific, Inc., Rochester, N. Y.) set at $70 \%$ maximum intensity. Insoluble material was sedimented at $27,000 \mathrm{~g}$ for $30 \mathrm{~min}$. $10 \mu \mathrm{l}$ of the supernate was then removed and added to $5 \mu 1$ EHNA at varying concentrations, and $30 \mu \mathrm{l}$ Tris-saline buffer in $12 \times 75-\mathrm{mm}$ plastic tubes (Falcon 2050). The enzymatic reaction was initiated by the addition of $5 \mu \mathrm{l}\left[8^{-{ }^{14}} \mathrm{C}\right]$ adenosine (Amersham/Searle, sp act $52 \mathrm{mCi} / \mathrm{mM}$ ) to a final concentration of $80 \mu \mathrm{M}$, and the sample was placed in a water bath at $37^{\circ} \mathrm{C}$. At time periods varying from 0 to 30 min after the addition of adenosine, $10 \mu \mathrm{l}$ of $8 \mathrm{M}$ formic acid was added, and the tubes were placed on ice. Then 10 $\mu 1$ of the mixture was spotted on cellulose thin layer sheets (13254, Eastern Kodak Co., Rochester, N. Y.) and developed in $1.0 \mathrm{M}$ ammonium acetate as described by $\mathrm{Mc}$ Burney (13) in the presence of appropriate carriers. After the plates were dry, the adenosine and inosine spots were visualized under ultraviolet light, cut out, and counted in a liquid scintillation counter. Using another solvent system (butanol: methanol: water: ammonium hydroxide, 60:20: $20: 1$ ), we had previously determined that less than $5 \%$ of inosine is converted to hypoxanthine under these conditions, and therefore hypoxanthine formation was not routinely measured.

Effect of Adenosine Deaminase Inhibitor 


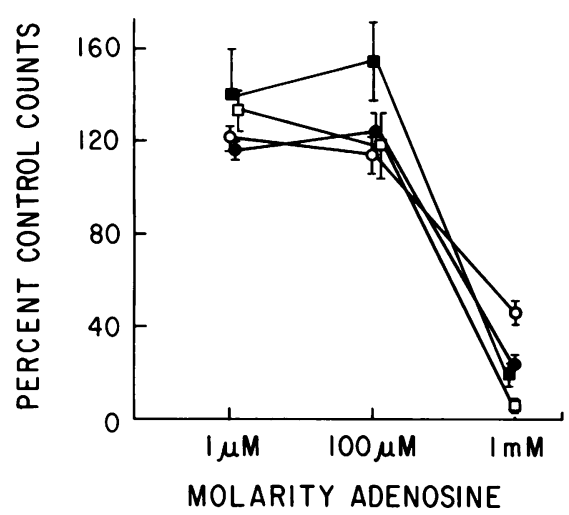

FIGURE 1 Effect of adenosine on $\left[6-{ }^{3} \mathrm{H}\right]$ thymidine uptake by mitogen-stimulated lymphocytes. Cells were cultured for $64 \mathrm{~h}$ in medium containing either $10 \%$ unheated human serum $(\mathrm{O}-\mathrm{O})$, human serum heated to $56^{\circ} \mathrm{C}$ for $1 \mathrm{~h}$ (-) ), gamma globulin-depleted horse serum ( $\square-\square)$, or no serum $(\square-\square)$, and varying concentrations of adenosine. $\left[6-^{3} \mathrm{H}\right]$ Thymidine was present during the last $16 \mathrm{~h}$ of culture. Results are expressed as the mean percent radioactivity incorporated when adenosine was present, compared to control cultures lacking adenosine. Each point for human serum is the mean of 20 cultures with Con A and pokeweed mitogen $\pm \mathrm{SEM}$; for horse serum, the results are derived from nine replicate cultures with pokeweed mitogen; the serum-free results represent the means of six cultures with Con A.

Statistical analysis. The absolute amount of radioactivity incorporated by mitogen-stimulated lymphocytes varied from day to day and among different subjects. To normalize the data, all cultures containing inhibitors of transformation were always compared with control cultures lacking inhibitors and processed on the same day. Results are expressed as percent control counts $=$ (counts incorporated in the presence of inhibitor/counts incorporated in the absence of inhibitor) $\times 100$. The results of multiple repetitive cultures on several different individuals were used to calculate a mean percent control counts \pm SE.M. Where applicable, the means of the drug-treated groups were compared, and the null hypothesis was accepted or rejected by the Mann-Whitney $U$ test (14). Two drugs were considered to have a synergistic effect when the inhibition produced by the drugs together was greater than the sum of the inhibitions when each drug was used separately.

Miscellaneous. EHNA was a gift of Dr. Howard Schaeffer. Adenosine, uridine, cytidine, orotic acid, butyric acid, norepinephrine, isoproterenol, and theophylline were purchased from Sigma and used without further purification. Adenosine $3^{\prime}, 5^{\prime}$-cyclic phosphate (cyclic AMP) and $\mathrm{N}^{6}, \mathrm{O}^{2}$ dibutyryl adenosine cyclic phosphate (dibutyryl cyclic AMP) were purchased as their sodium salts from P-L Biochemicals (Milwaukee, Wis.). All reagents were dissolved in RPMI 1640 and sterilized by ultrafiltration before use.

\section{RESULTS}

Effects of exogenous adenosine. Adenosine added at the time of initiation of lymphocyte cultures did not im- pair the subsequent incorporation of $\left[6{ }^{8} \mathrm{H}\right]$ thymidine until millimolar concentrations were reached (Fig. 1). At lower doses (10-100 $\mu \mathrm{M})$, exogenous adenosine had a slight but significant $(P<0.005)$ stimulatory effect on thymidine uptake.

The characteristic dose-response curve observed with the addition of exogenous adenosine was independent of the type of mitogen (pokeweed or Con A), the concentration of mitogen, or the medium used (RPMI 1640 or Eagle's minimal essential medium). Diminishing or removing adenosine deaminase from the medium did, however, increase the toxicity of adenosine. By heating the human serum in which the cells were cultured to $56^{\circ} \mathrm{C}$ for $1 \mathrm{~h}$, which partially denatures adenosine deaminase (15), or by using horse serum, which lacks detectable enzyme, the inhibition of thymidine uptake seen with millimolar concentrations of adenosine was increased from $56 \%$ to $78 \%(P<0.005)$.

The dose-response curve seen with varying concentrations of adenosine did not differ significantly when a 4-h rather than a $16-\mathrm{h}$ pulse of tritiated thymidine was used.

As shown in Table I, concentrations of adenosine as low as $15 \mu \mathrm{M}$ significantly inhibited the incorporation of tritiated leucine into protein $(P<0.005)$. Lower concentrations of adenosine did not stimulate leucine uptake.

Effects of EHNA. The adenosine deaminase inhibitor EHNA did not inhibit thymidine uptake until a concentration of $100 \mu \mathrm{M}$ was reached (Table II). At a concentration of $10 \mu \mathrm{M}$, EHNA, like adenosine, increased thymidine uptake, although at the same concentration,

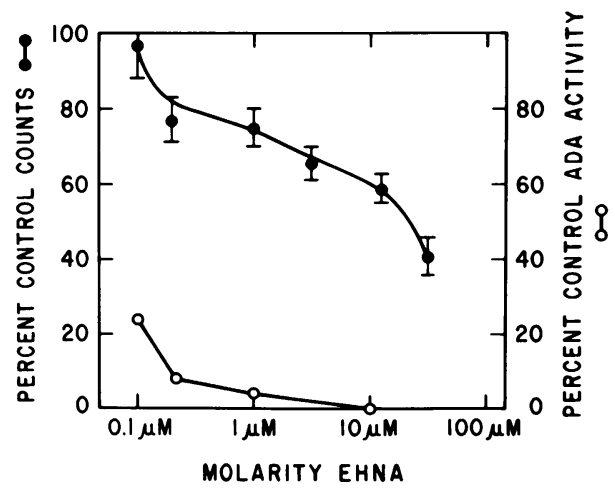

FIGURE 2 Inhibition of $\mathrm{L}-\left[4,5-{ }^{3} \mathrm{H}\right]$ leucine incorporation into protein, and of adenosine deaminase (ADA), by EHNA. Con A-stimulated cells were cultured for $64 \mathrm{~h}$ in heatinactivated human serum containing the indicated concentrations of EHNA. L- $\left[4,5-{ }^{\circ} \mathrm{H}\right]$ Leucine was present during the last $4 \mathrm{~h}$. The mean percent radioactivity $(\bullet-\bullet)$ incorporated into protein, derived from nine replicate cultures, was determined as described in Fig. 1. The open circles $(\mathrm{O}-\mathrm{O})$ show the effect of similar concentrations of EHNA upon the adenosine deaminase activity of a lymphocyte extract. 
TABLE I

Synergy between Adenosine, Cyclic AMP, and EHNA in the Inhibition of L- $\left[4,5-{ }^{3} H\right] L e u c i n e$ Incorporation into Protein by Mitogen-Stimulated Lymphocytes

\begin{tabular}{|c|c|c|c|c|c|c|c|c|c|c|}
\hline \multirow[b]{2}{*}{ EHNA } & \multicolumn{5}{|c|}{ Molarity adenosine } & \multicolumn{5}{|c|}{ Molarity cyclic AMP } \\
\hline & 0 & $5 \mu \mathrm{M}$ & $15 \mu \mathrm{M}$ & $50 \mu \mathrm{M}$ & $100 \mu \mathrm{M}$ & $1 \mathrm{mM}$ & $10 \mu \mathrm{M}$ & $100 \mu \mathrm{M}$ & $1 \mathrm{mM}$ & $3 \mathrm{mM}$ \\
\hline$\mu M$ & \multicolumn{10}{|c|}{$\%$ of control counts } \\
\hline 0 & 100 & $\begin{array}{l}100 \pm 2 \\
n=17\end{array}$ & $\begin{array}{c}87 \pm 4 \\
n=18\end{array}$ & $\begin{array}{c}84 \pm 5 \\
n=18\end{array}$ & $\begin{array}{c}79 \pm 4 \\
n=21\end{array}$ & $\begin{array}{c}14 \pm 1 \\
n=21\end{array}$ & $\begin{array}{c}86 \pm 5 \\
n=12\end{array}$ & $\begin{array}{c}81 \pm 5 \\
n=12\end{array}$ & $\begin{array}{c}65 \pm 4 \\
n=12\end{array}$ & $\begin{array}{c}46 \pm 3 \\
n=12\end{array}$ \\
\hline 0.1 & $\begin{array}{r}95 \pm 5 \\
n=12\end{array}$ & $\begin{array}{c}85 \pm 4 \\
n=6\end{array}$ & $\begin{array}{c}86 \pm 3 \\
n=6\end{array}$ & $\begin{array}{c}55 \pm 3 \\
n=6\end{array}$ & $\begin{array}{c}39 \pm 3 \\
n=3\end{array}$ & ND & ND & ND & ND & \\
\hline 1.0 & $\begin{array}{c}75 \pm 5 \\
n=9\end{array}$ & $\begin{array}{c}65 \pm 5 \\
n=9\end{array}$ & $\begin{array}{c}47 \pm 1 \\
n=9\end{array}$ & $\begin{array}{c}30 \pm 3 \\
n=9\end{array}$ & $\begin{array}{c}23 \pm 2 \\
n=9\end{array}$ & $\begin{array}{l}\text { ND } \\
\text { ND }\end{array}$ & $\begin{array}{c}65 \pm 6 \\
n=9\end{array}$ & $\begin{array}{c}61 \pm 4 \\
n=9\end{array}$ & $\begin{array}{c}23 \pm 3 \\
n=9\end{array}$ & \\
\hline 5.0 & $\begin{array}{r}66 \pm 4 \\
n=21\end{array}$ & $\begin{array}{r}52 \pm 2 \\
n=18\end{array}$ & $\begin{array}{c}37 \pm 4 \\
n=18\end{array}$ & $\begin{array}{c}26 \pm 4 \\
n=18\end{array}$ & $\begin{array}{c}15 \pm 1 \\
n=15\end{array}$ & ND & $\begin{array}{c}58 \pm 4 \\
n=12\end{array}$ & $\begin{array}{c}50 \pm 3 \\
n=12\end{array}$ & $\begin{array}{c}18 \pm 1 \\
n=12\end{array}$ & \\
\hline $\begin{array}{l}15 \\
50\end{array}$ & $\begin{array}{c}59 \pm 4 \\
n=9 \\
41 \pm 4 \\
n=9\end{array}$ & $\begin{array}{c}46 \pm 4 \\
n=9\end{array}$ & $\begin{array}{c}40 \pm 1 \\
n=9\end{array}$ & $\begin{array}{c}11 \pm 2 \\
n=9\end{array}$ & $\begin{array}{c}9 \pm 1 \\
n=6\end{array}$ & & & & & \\
\hline
\end{tabular}

Results are expressed as the mean percent control counts \pm SEM for the indicated number of cultures. ND, not done.

adenosine deaminase activity in lymphocyte extracts could be $99 \%$ inhibited (Fig. 2). On the other hand, when leucine incorporation into protein was measured, EHNA concentrations as low as $0.3 \mu \mathrm{M}$ had a significant inhibitory effect $(P<0.01)$, at which concentration the adenosine deaminase activity in lymphocyte extracts was $90 \%$ inhibited.

Potentiation of adenosine inhibition by EHNA. In the presence of $50 \mu \mathrm{M}$ EHNA, adenosine at concentrations as low as $10 \mu \mathrm{M}$ inhibited thymidine uptake ( $\mathrm{Ta}$ -

TABLE II

Synergy between Adenosine and EHNA in the Inhibition of $\left[6-{ }^{3} H\right]$ Thymidine Uptake by Mitogen-Stimulated Lymphocytes

\begin{tabular}{cccccc}
\hline & \multicolumn{5}{c}{ Adenosine concentration } \\
\cline { 2 - 5 } EHNA & 0 & $10 \mu \mathrm{M}$ & $50 \mu \mathrm{M}$ & $100 \mu \mathrm{M}$ & $1 \mathrm{mM}$ \\
\hline & $100 \pm 1$ & $117 \pm 4$ & $123 \pm 8$ & $121 \pm 7$ & $22 \pm 2$ \\
0 & $n=51$ & $n=19$ & $n=52$ & $n=20$ & $n=18$ \\
$10 \mu \mathrm{M}$ & $119 \pm 5$ & $120 \pm 8$ & $83 \pm 6$ & $84 \pm 5$ \\
& $n=30$ & $n=12$ & $n=13$ & $n=3$ \\
$50 \mu \mathrm{M}$ & $96 \pm 4$ & $78 \pm 7$ & $46 \pm 8$ & $18 \pm 1$ \\
& $n=51$ & $n=14$ & $n=16$ & $n=3$ \\
$100 \mu \mathrm{M}$ & $66 \pm 14$ & & & \\
& $n=6$ & & & \\
$1 \mathrm{mM}$ & $2 \pm 1$ & & & \\
& $n=3$ & & &
\end{tabular}

Results are expressed as the mean percent control counts $\pm \mathrm{SEM}$ for the indicated number of cultures. ble II). An EHNA concentration of $0.1 \mu \mathrm{M}$ or greater was effective in potentiating the inhibitory effects of adenosine on protein synthesis $(P<0.05)$ (Table I).

Effect of uridine. The presence of uridine in the medium at a concentration of $10 \mu \mathrm{M}$ substantially diminished but did not completely reverse the inhibitory effects of adenosine on thymidine and leucine uptake (Fig. 3). At higher concentrations, uridine inhibited thymidine uptake, probably by competing for a com-

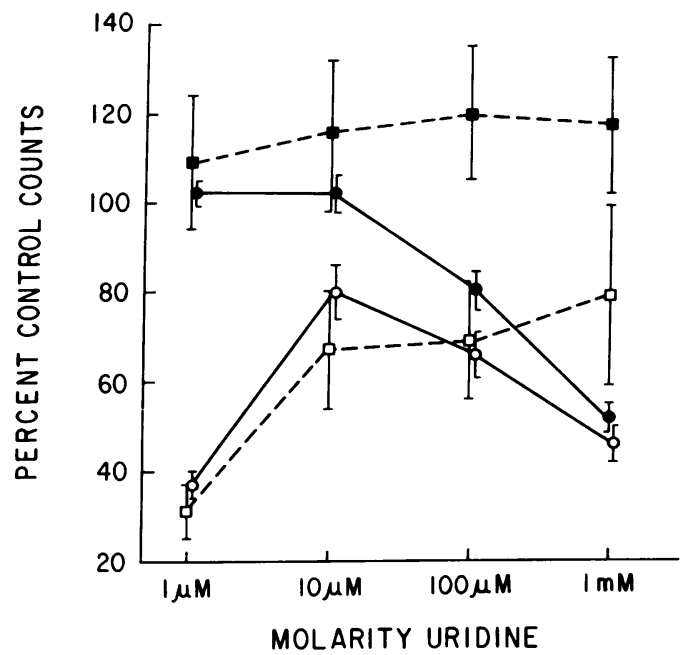

FIgURE 3 Uridine reversal of adenosine toxicity in Con Astimulated lymphocytes. Cells were cultured with the indicated concentrations of uridine, either with or without 1 $\mathrm{mM}$ adenosine. Thymidine uptake was determined in the presence $(\mathrm{O}-\mathrm{O})$ and absence $(-\bullet)$ of adenosine; leucine incorporation was similarly determined either with $(\square-\square)$ or without ( $\square-\boldsymbol{\square})$ adenosine present.

Effect of Adenosine Deaminase Inhibitor 
TABLE III

Effect of Cyclic AMP and Dibutyryl Cyclic AMP upon $\left[6-{ }^{3} H\right]$ Thymidine Uptake in Mitogen-Stimulated Lymphocytes

\begin{tabular}{|c|c|c|c|c|c|c|}
\hline Inhibitor & Concentration & $\begin{array}{c}\text { +EHNA } \\
50 \mu \mathrm{M}\end{array}$ & $\begin{array}{c}\text { +Uridine } \\
10 \mu \mathrm{M}\end{array}$ & $\begin{array}{l}\text { Number of } \\
\text { cultures }\end{array}$ & $\begin{array}{l}\text { Mean control } \\
\text { counts* }\end{array}$ & $P \ddagger$ \\
\hline & $M$ & & & & $\%$ & \\
\hline \multirow[t]{8}{*}{ Cyclic AMP } & $100 \mu \mathrm{M}$ & no & no & 9 & $116 \pm 4$ & \\
\hline & $100 \mu \mathrm{M}$ & yes & no & 6 & $79 \pm 3$ & $<0.005$ \\
\hline & $1 \mathrm{mM}$ & no & no & 9 & $85 \pm 4$ & \\
\hline & $1 \mathrm{mM}$ & yes & no & 6 & $25 \pm 5$ & $<0.005$ \\
\hline & $1 \mathrm{mM}$ & no & yes & 9 & $127 \pm 10$ & $<0.005$ \\
\hline & $3 \mathrm{mM}$ & no & no & 6 & $40 \pm 3$ & \\
\hline & $3 \mathrm{mM}$ & yes & no & 6 & $17 \pm 4$ & $<0.005$ \\
\hline & $3 \mathrm{mM}$ & no & yes & 6 & $102 \pm 6$ & $<0.005$ \\
\hline \multirow[t]{8}{*}{ Dibutyryl cyclic AMP } & $10 \mu \mathrm{M}$ & no & no & 8 & $97 \pm 4$ & \\
\hline & $10 \mu \mathrm{M}$ & yes & no & 6 & $87 \pm 3$ & $<0.05$ \\
\hline & $100 \mu \mathrm{M}$ & no & no & 18 & $65 \pm 2$ & \\
\hline & $100 \mu \mathrm{M}$ & yes & no & 12 & $42 \pm 3$ & $<0.005$ \\
\hline & $100 \mu \mathrm{M}$ & no & yes & 15 & $76 \pm 5$ & NS§ \\
\hline & $1 \mathrm{mM}$ & no & no & 12 & $35 \pm 4$ & \\
\hline & $1 \mathrm{mM}$ & yes & no & 6 & $6 \pm 1$ & $<0.005$ \\
\hline & $1 \mathrm{mM}$ & no & yes & 9 & $41 \pm 4$ & NS \\
\hline \multirow[t]{7}{*}{ Butyric acid } & $30 \mu \mathrm{M}$ & no & no & 6 & $101 \pm 2$ & \\
\hline & $30 \mu \mathrm{M}$ & yes & no & 6 & $113 \pm 5$ & NS \\
\hline & $100 \mu \mathrm{M}$ & no & no & 15 & $87 \pm 2$ & \\
\hline & $100 \mu \mathrm{M}$ & yes & no & 17 & $83 \pm 5$ & NS \\
\hline & $0.5 \mathrm{mM}$ & no & no & 12 & $55 \pm 1$ & \\
\hline & $0.5 \mathrm{mM}$ & yes & no & 11 & $21 \pm 2$ & $<0.005$ \\
\hline & $1 \mathrm{mM}$ & no & no & 3 & $12 \pm 1$ & \\
\hline
\end{tabular}

* Values reported are the mean percent control counts \pm SEM for the indicated number of cultures.

$\ddagger$ The significance values compare the means of cultures containing EHNA or uridine plus a given inhibitor with cultures containing the inhibitor alone. Uridine and EHNA at these concentrations had no effect on thymidine uptake.

$\S$ Not significant $(P>0.05)$.

mon transport site, but had no effect on the incorporation of tritiated leucine into protein. In other experiments (results not shown) cytidine was also partially able to prevent adenosine toxicity, while orotic acid and theophylline over a wide concentration range were ineffective. Uridine did not protect cells from the inhibitory effects of EHNA; neither did a combination of uridine plus adenosine. Millimolar concentrations of adenosine did not diminish cell viability after $60 \mathrm{~h}$, as measured by trypan blue exclusion.

Effect of time of addition of adenosine. In one experiment lymphocytes were cultured in the presence of $50 \mu \mathrm{M}$ EHNA, and at varying time periods after the addition of Con $\mathrm{A}$, adenosine was added to a final concentration of $50 \mu \mathrm{M}$. All cultures were harvested $64 \mathrm{~h}$ after the addition of mitogen. As expected, the later the adenosine was added, the less it inhibited the subsequent uptake of tritiated thymidine (Fig. 4). Similarly, when Con A-stimulated lymphocytes were cultured in the presence of $50 \mu \mathrm{M}$ EHNA and $50 \mu \mathrm{M}$ adenosine and the inhibitors were washed out at varying time periods, diminished inhibition was observed. There was no apparent critical period early in immune induction during which adenosine exerted its inhibitory effects. Rather, the percent inhibition observed when adenosine and EHNA were incubated with lymphocytes was proportional to the length of time the agents were in contact with the cells, whether this occurred early or late after the addition of mitogen.

Effect of exogenous cyclic AMP and dibutyryl cyclic $A M P$. The addition of exogenous cyclic AMP to lymphocyte cultures did not inhibit thymidine uptake until millimolar concentrations were reached (Table III). At a cyclic AMP concentration of $100 \mu \mathrm{M}$, thymidine uptake was increased $16 \%$ over control values $(P<$ $0.005)$. Cyclic AMP concentrations as low as $10 \mu \mathrm{M}$ inhibited the incorporation of tritiated leucine into protein $(P<0.01)$ (Table I).

Dibutyryl cyclic AMP, on a molar basis, was more than 10 times as potent as cyclic AMP as an inhibitor 
of thymidine uptake (Table III). In addition it did not stimulate thymidine uptake at concentrations as low as $0.001 \mu \mathrm{M}$. In control experiments, at least part of the effect of dibutyryl cyclic AMP could be attributed to its breakdown product butyric acid, particularly at concentrations greater than $100 \mu \mathrm{M}$. Monobutyryl cyclic AMP, however, was just as effective an inhibitor as dibutyryl cyclic AMP (results not shown), although only one half as much butyric acid could be generated.

The presence of $10 \mu \mathrm{M}$ uridine in the medium was able to protect the lymphocytes from the inhibitory effects of exogenous cyclic AMP. On the other hand, uridine had no effect on the toxicity of dibutyryl cyclic AMP.

The adenosine deaminase inhibitor EHNA at a concentration of $50 \mu \mathrm{M}$ potentiated the inhibitory effects of cyclic AMP and, to a lesser degree, dibutyryl cyclic AMP on thymidine uptake (Table III). Thus, at a concentration of $1 \mathrm{mM}$ cyclic AMP, tritiated thymidine uptake was $85 \pm 4 \%$ of control values; the addition of 50 $\mu \mathrm{M}$ EHNA lowered this to $25 \pm 5 \%(P<0.005)$. The addition of EHNA to cultures containing $10 \mu \mathrm{M}$ dibutyryl cyclic AMP lowered tritiated thymidine uptake from $65 \pm 2$ to $42 \pm 3 \%$ of controls $(P<0.005)$. In other experiments (results not shown), EHNA was unable to potentiate the inhibitory effects of dibutyryl cyclic AMP upon leucine incorporation into protein.

Effect of pharmacologic agents. Because of difficulties in ascertaining how much of the effects of dibutyryl cyclic AMP were actually due to butyric acid, we also tested the effects of EHNA and uridine in modifying the inhibition of thymidine uptake caused by norepinephrine, isoproterenol, and theophylline (Table IV). EHNA at a concentration of $50 \mu \mathrm{M}$ significantly enhanced the toxicity observed at 30 and $100 \mu \mathrm{M}$ concentrations of norepinephrine $(P<0.005)$. The effect of EHNA on isoproterenol was marginal until $100 \mu \mathrm{M}$ concentrations of the latter compound were reached, at which point significant enhancement was observed $(P<0.05)$. EHNA had no effect on the inhibition of thymidine uptake caused by theophylline at concentrations as high as $1 \mathrm{mM}$.

In other experiments (results not shown) adenosine alone at concentrations up to $100 \mu \mathrm{M}$ did not potentiate norepinephrine toxicity. EHNA had no effect upon the inhibition of leucine uptake induced by norepinephrine, isoproterenol, or theophylline. Uridine was unable to re-

TABLE IV

Effect of Norepinephrine, Isoproterenol, and Theophylline upon $\left[6-{ }^{3} \mathrm{H}\right] T$ Thymidine Uptake in Mitogen-Stimulated Lymphocytes.

\begin{tabular}{|c|c|c|c|c|c|c|}
\hline Inhibitor & Concentration & $\begin{array}{c}\text { +EHNA } \\
50 \mu \mathrm{M}\end{array}$ & $\begin{array}{c}\text { +Uridine } \\
10 \mu \mathrm{M}\end{array}$ & $\begin{array}{l}\text { Number of } \\
\text { cultures }\end{array}$ & $\begin{array}{l}\text { Mean percent* } \\
\text { control counts }\end{array}$ & $P$ \\
\hline & & & & & $\%$ & \\
\hline \multirow[t]{7}{*}{ Norepinephrine } & $30 \mu \mathrm{M}$ & no & no & 12 & $83 \pm 2$ & \\
\hline & $30 \mu \mathrm{M}$ & yes & no & 12 & $51 \pm 2$ & $<0.005$ \\
\hline & $100 \mu \mathrm{M}$ & no & no & 24 & $43 \pm 3$ & \\
\hline & $100 \mu \mathrm{M}$ & yes & no & 24 & $8 \pm 2$ & $<0.005$ \\
\hline & $100 \mu \mathrm{M}$ & no & yes & 9 & $51 \pm 6$ & NS \\
\hline & $0.25 \mathrm{mM}$ & no & no & 3 & $22 \pm 1$ & \\
\hline & $0.25 \mathrm{mM}$ & no & yes & 3 & $20 \pm 2$ & NS \\
\hline \multirow[t]{7}{*}{ Isoproterenol } & $10 \mu \mathrm{M}$ & no & no & 15 & $89 \pm 2$ & \\
\hline & $10 \mu \mathrm{M}$ & yes & no & 15 & $79 \pm 8$ & NS \\
\hline & $30 \mu \mathrm{M}$ & no & no & 11 & $85 \pm 2$ & \\
\hline & $30 \mu \mathrm{M}$ & yes & no & 12 & $91 \pm 4$ & NS \\
\hline & $100 \mu \mathrm{M}$ & no & no & 12 & $35 \pm 8$ & \\
\hline & $100 \mu \mathrm{M}$ & yes & no & 12 & $11 \pm 4$ & $<0.05$ \\
\hline & $100 \mu \mathrm{M}$ & no & yes & 6 & $39 \pm 18$ & NS \\
\hline \multirow[t]{9}{*}{ Theophylline } & $50 \mu \mathrm{M}$ & no & no & 4 & $101 \pm 2$ & \\
\hline & $100 \mu \mathrm{M}$ & no & no & 11 & $88 \pm 3$ & \\
\hline & $100 \mu \mathrm{M}$ & yes & no & 11 & $94 \pm 4$ & NS \\
\hline & $100 \mu \mathrm{M}$ & no & yes & 3 & $81 \pm 2$ & NS \\
\hline & $0.5 \mathrm{mM}$ & no & no & 22 & $67 \pm 2$ & \\
\hline & $0.5 \mathrm{mM}$ & yes & no & 18 & $67 \pm 6$ & NS \\
\hline & $0.5 \mathrm{mM}$ & no & yes & 6 & $51 \pm 3$ & NS \\
\hline & $1 \mathrm{mM}$ & no & no & 6 & $39 \pm 1$ & \\
\hline & $1 \mathrm{mM}$ & yes & no & 6 & $36 \pm 5$ & NS \\
\hline
\end{tabular}

* The mean percent control counts and the significance values were determined as described in Table III. 


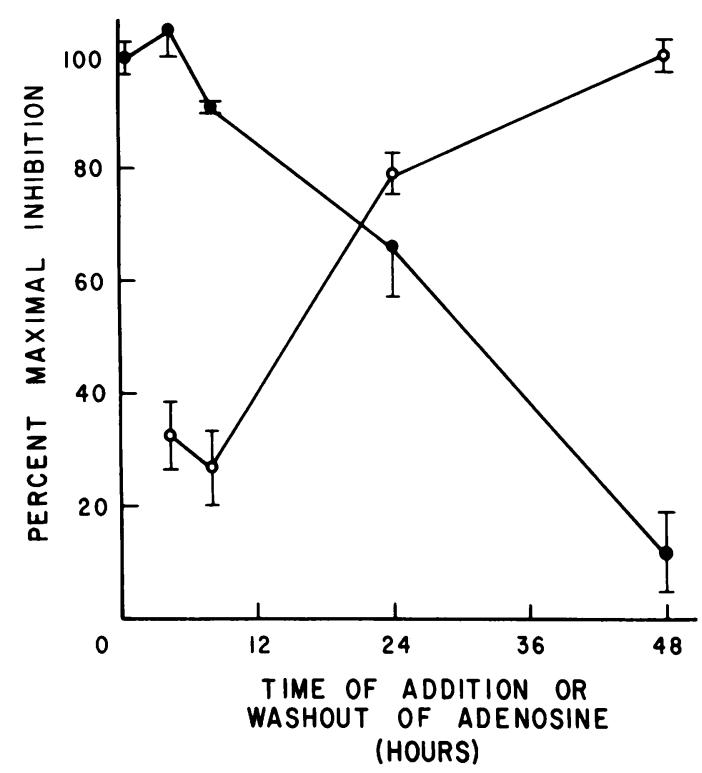

Figure 4 Effect of time of addition or washout of adenosine upon the subsequent incorporation of $\left[6-{ }^{3} \mathrm{H}\right]$ thymidine by Con A-stimulated lymphocytes. Two types of experiments were done. In the first, cells were incubated at time zero with mitogen and $50 \mu \mathrm{M}$ EHNA (-๑); at the times indicated adenosine was added to a concentration of $50 \mu \mathrm{M}$ and thymidine incorporation was determined at $64 \mathrm{~h}$. In the second experiment, cells were incubated with mitogen plus $50 \mu \mathrm{M}$ EHNA and $50 \mu \mathrm{M}$ adenosine $(\mathrm{O}-\mathrm{O})$ in $12 \times 75-\mathrm{mm}$ tubes. At the times indicated, they were washed and resuspended in the identical medium without inhibitors. The results of triplicate cultures are expressed as: mean percent maximal inhibition $=100 \times(1-$ radioactivity incorporated when cells were exposed to inhibitors for a limited time/radioactivity incorporated when cells were exposed continuously to inhibitors.).

verse the inhibition of thymidine or leucine uptake cansed by norepinephrine, isoproterenol, or theophylline.

\section{DISCUSSION}

In the experiments reported here, we have examined in detail the effect of inhibition of adenosine deaminase upon the response of normal peripheral blood lymphocytes to mitogens. The addition of the adenosine deaminase inhibitor EHNA at concentrations as low as 0.3 $\mu \mathrm{M}$ to Con A-stimulated lymphocytes impaired the subsequent incorporation of tritiated leucine into protein. At this concentration of EHNA, the adenosine deaminase activity of a lymphocyte extract was inhibited $90 \%$. In our laboratory, concentrations of EHNA at least 10 times higher are necessary to inhibit the growth of longterm human lymphocyte and fibroblast lines. Thus the normal human peripheral blood lymphocyte undergoing blastogenesis is a cell particularly susceptible to the effects of adenosine deaminase inhibition.

Thymidine uptake was a far less sensitive index of
EHNA toxicity than leucine uptake, probably due to an adenosine-like effect of EHNA. Hilz and Kaukel have shown in isolated HeLa cells that adenosine, by depleting pyrimidine nucleotide pools, could proportionally increase the specific activity of added tritiated thymidine or uridine $(16,17)$. This led to the paradoxical effect of an increase in thymidine incorporation into DNA at a time when cell growth was actually inhibited. It is likely that EHNA, being an adenosine analogue, can in high concentrations also decrease pyrimidine nucleotide pools. Thus EHNA at a concentration of $10 \mu \mathrm{M}$, when leucine incorporation was inhibited $40 \%$, actually increased thymidine uptake. The incorporation of uridine into RNA, while not specifically measured, would be expected to behave similarly.

The addition of adenosine to mitogen-stimulated lymphocytes also had a biphasic effect on tritiated thymidine uptake, with stimulation at low doses and inhibition at millimolar concentrations. The apparent stimulation is consistent with its known effect on reducing the size of pyrimidine nucleotide pools (16-18). Here again, leucine incorporation into protein was a more sensitive indicator of adenosine toxicity, with inhibition at concentrations of adenosine as low as $15 \mu \mathrm{M}$. The simultaneous presence of EHNA in the culture medium enhanced the inhibition of blastogenesis induced by adenosine. Concentrations as low as $0.1 \mu \mathrm{M}$ EHNA plus $5 \mu \mathrm{M}$ adenosine significantly inhibited leucine incorporation $(P<$ 0.05 ).

The above results do not necessarily indicate that the impairment of lymphocyte proliferation associated with adenosine deaminase inhibition is actually the result of adenosine toxicity, since intracellular adenosine levels were never measured. Indeed, in certain respects the toxicity of EHNA and adenosine differed. For example, uridine was able to reverse partially the inhibitory effects of adenosine, but not EHNA, on thymidine and leucine uptake. Adenosine in high concentrations blocks both de novo purine and pyrimidine biosynthesis by decreasing the formation of phosphoribosyl pyrophosphate. When uridine is in the medium, de novo pyrimidine synthesis is unnecessary for cell survival, and adenosine itself can function as a purine source. EHNA, being nonmetabolizable, cannot function as a source of purines; therefore, uridine should not reverse the inhibitory effects of EHNA. Even a mixture of adenosine and uridine, however, was without effect on EHNA toxicity, indicating that some of the inhibitory effects of EHNA are not related to inhibition of de novo purine and pyrimidine synthesis.

In mouse and human lymphocytes, incubation with pharmacologic concentrations of adenosine $(375 \mu \mathrm{M})$ leads to a rise in intracellular cyclic AMP concentrations, an effect that can be potentiated but not simulated 
by EHNA (8). This result suggested that some of the immunosuppressive effects of adenosine might be mediated by cyclic AMP, since exogenous cyclic AMP and agents that elevate intracellular cyclic AMP levels can inhibit both lymphocyte transformation and antibody secretion $(5,6,19,20)$. It must be remembered, however, that intracellular adenosine is converted to adenine nucleotides by adenosine kinase (21), and might secondarily increase cyclic AMP concentrations simply by enlarging precursor pools.

Our approach to this problem was to see if EHNA could potentiate the effects of exogenous cyclic AMP, dibutyryl cyclic AMP, and pharmacologic agents that elevate intracellular cyclic AMP concentrations. The effects of exogenous cyclic AMP upon tritiated thymidine uptake were similar to those of adenosine, with stimulation at low doses, inhibition at millimolar concentrations, potentiation by EHNA, and prevention of toxicity by uridine. On the contrary, dibutyryl cyclic AMP, isoproterenol, norepinephrine, and theophylline failed to stimulate thymidine uptake at any concentration, and their inhibitory effects were unmodified by uridine. The identity of the effects of adenosine and exogenous cyclic AMP and the differing effects of dibutyryl cyclic AMP suggest that the actions of exogenous cyclic AMP are actually mediated by the adenosine to which it is metabolized, as has been previously suggested $(6,22)$.

When tritiated thymidine uptake was used as an assay of transformation, EHNA at a concentration of 50 $\mu \mathrm{M}$ (the highest noninhibitory dose) did potentiate the effects of dibutyryl cyclic AMP, norepinephrine, and isoproterenol. It had no effect on theophylline-induced inhibition of thymidine uptake, and indeed, in neuronal cells theophylline has been reported to be an inhibitor of adenosine-mediated elevations of cyclic AMP concentrations $(11,23)$. Taken alone, these results suggest that adenosine deaminase inhibition can augment the effects of cyclic AMP. Other experiments, however, failed to support this conclusion. Theophylline was not able to prevent adenosine toxicity. In addition, EHNA at concentrations lower than $50 \mu \mathrm{M}$ did not enhance the inhibitory effects of dibutyryl cyclic AMP, norepinephrine, or isoproterenol on either thymidine or leucine uptake, at which concentrations synergy with adenosine was readily apparent. The leucine uptake studies further showed that $50 \mu \mathrm{M}$ EHNA was actually toxic to lymphocytes, but that this effect was masked when thymidine uptake was measured.

To summarize, our results suggest that inhibition of adenosine deaminase with EHNA can depress human lymphocyte blastogenesis. In an experimentally expanding lymphocyte population, even a small decrease in the number of cells dividing, or in the rate of division, could result in severe lymphopenia.
We were unable to determine the exact biochemical mechanisms by which EHNA interfered with lymphocyte proliferation. Inhibition of adenosine deaminase with EHNA did not consistently potentiate the effect of agents that elevate intracellular cyclic AMP concentrations. EHNA did sensitize lymphocytes to the toxic effects of exogenous adenosine and cyclic AMP, presumably by blocking their further metabolism. However, EHNA toxicity, unlike that of adenosine and cyclic AMP, was not reversed by uridine. These results suggest that EHNA-mediated inhibition of lymphocyte transformation does not result from the accumulation of intracellular adenosine or adenine nucleotides. The possibility remains, however, that in patients with adenosine deaminase deficiency, elevated concentrations of circulating adenosine or adenine nucleotides, derived from extracellular, nonlymphoid sources, depress immune development.

Finally, our results also illustrate the difficulties inherent in using thymidine or uridine uptake as indices of lymphocyte blastogenesis. One must remember that any agents, such as adenosine and cyclic AMP, that alter nucleoside transport or intracellular nucleotide pools can either increase or decrease thymidine and uridine uptake independently of any effects on cellular proliferation.

\section{ACKNOWLEDGMENTS}

The authors would like to acknowledge the technical assistance of Ms. Rebecca Trafzer.

This study was supported by National Institutes of Health grants AM-13622 and GM-17702, and by grants from the Kroc Foundation and the National Foundation.

\section{REFERENCES}

1. Giblett, E. R., J. E. Anderson, F. Cohen, B. Pollara, and H. J. Meuwissen. 1972. Adenosine-deaminase deficiency in two patients with impaired cellular immunity. Lancet. 2 : 1067-1069.

2. Dissing, J., and B. Knudsen. 1972. Adenosine deaminase deficiency and combined immunodeficiency syndrome. Lancet. 2 : 1316-1318.

3. Yount, J., P. Nichols, H. D. Ochs, S. P. Hammar, C. R. Scott, S.-H. Chen, E. R. Giblett, and R. J. Wedgwood. 1974. Absence of erythrocyte adenosine deaminase associated with severe combined immunodeficiency. $J$. Pediatr. 84 : 173-177.

4. Pickering, R. J., B. Pollara, and H. J. Meuwissen. 1974. Meeting report. Workshop on severe combined immunological deficiency and adenosine deaminase deficiency. Clin. Immunol. Immunopathol. 3: 310-307.

5. Hirschorn, R., J. Grossman, and G. Weissmann. 1970. Effect of cyclic $3^{\prime}, 5^{\prime}$-adenosine monophosphate and theophylline on lymphocyte transformation. Proc. Soc. Exp. Biol. Med. 133: 1361-1365.

6. Smith, J. W., A. I. Steiner, and C. W. Parker. 1971. Human lymphocyte metabolism. Effects of cyclic and

Effect of Adenosine Deaminase Inhibitor 
noncyclic nucleotides on stimulation by phytohemagglutinin. J. Clin. Invest. 50: 442-448.

7. Green, H., and T.-S. Chan. 1973. Pyrimidine starvation induced by adenosine in fibroblasts and lymphoid cells. Role of adenosine deaminase. Science (Wash. D. C.). 182 : 836-837.

8. Wolberg, G., T. P. Zimmerman, K. Hiemstra, M. Winston, and L.-C. Chu. 1975. Adenosine inhibition of lymphocyte-mediated cytolysis: possible role of cyclic adenosine monophosphate. Science (Wash. D. C.). 187: 957-959.

9. Schaeffer, H. J., and G. F. Schwende. 1974. Enzyme inhibitors 26. Bridging hydrophobic and hydrophilic regions on adenosine deaminase with some 9-(2-hydroxy-3-alkyl) adenines. J. Med. Chem. 17: 6-8.

10. Sattin, A. and T. W. Rall. 1970. The effect of adenosine and adenine nucleotides on the cyclic adenosine $3^{\prime}-5^{\prime}$-phosphate content of guinea pig cerebral cortex slices. Mol. Pharmacol. 6: 13-23.

11. Blume, A. J., C. Dalton, and H. Sheppard. 1973. Adenosine-mediated elevation of cyclic $3^{\prime}: 5^{\prime}$-adenosine monophosphate concentrations in cultured mouse neuroblastoma cells. Proc. Natl. Acad. Sci. U. S. A. 70: 30993102.

12. Giblett, E. R., A. J. Amman, R. Sandman, D. W. Wara, and L. K. Diamond. 1975. Nucleoside phosphorylase deficiency in a child with severely defective T-cell immunity and normal B-cell immunity. Lancet. 2: 1010 1013.

13. McBurney, M. W., and G. F. Whitmore. 1975. Mutants of Chinese hamster cells resistant to adenosine. J. Cell. Physiol. 85 : 87-100.

14. Bruning, J. L., and B. L. Kintz. 1968. Computational Handbook of Statistics. Scott, Foresman, and Company, Glenview, III. 201-204.

15. Osborne, W. R. A., and N. Spencer. 1973. Partial purification and properties of the common inherited forms of adenosine deaminase from human erythrocytes. Biochem. J. 133: 117-123.

16. Kaukel, E., U. Fuhrmann, and H. Hilz. 1972. Divergent action of cAMP and dibutyryl cAMP on macromolecular synthesis in HeLa S3 cultures. Biochem. Biophys. Res. Commun. 48: 1516-1524.

17. Hilz, H., and E. Kaukel. 1973. Divergent action mechanism of cAMP and dibutyryl cAMP on cell proliferation and macromolecular synthesis in HeLa S3 cultures. Mol. Cell Biochem. 1: 229-239.

18. Ishii, K., and H. Green. 1973. Lethality of adenosine for cultured mammalian cells by interference with pyrimidine biosynthesis. J. Cell Sci. 13: 429-439.

19. Hadden, J. W., E. M. Hadden, and E. Middleton, Jr. 1970. Lymphocyte blast transformation. I. Demonstration of adrenergic receptors in human peripheral lymphocytes. Cell. Immunol. 1 : 583-595.

20. Bourne, H. F., K. L. Melmon, Y. Weinstein, and G. M. Shearer. 1974. Pharmacological regulation of antibody release in vitro: Effects of vasoactive amines and cyclic AMP. In Cyclic AMP, Cell Growth and the Immune Response. W. Braun, L. M. Lichtenstein, and C. W. Parker, editors. Springer-Verlag New York Inc., New York. 1st edition. 99-113.

21. Snyder, F. F., and J. F. Henderson. 1973. Pathways of deoxyadenosine and adenosine metabolism. J. Biol. Chem. 248: 5899-5904.

22. Hirshhorn, R. 1974. The effects of exogenous nucleotides on the response of lymphocytes to PHA, PWM and Con A. In Cyclic AMP, Cell Growth and the Immune Response. W. Braun, L. M. Lichtenstein, and C. W. Parker, editors. Springer-Verlag New York, Inc., New York. 1st edition. 45-54.

23. Clark, R. B., R. Gross, Y. F. Su, and J. F. Perkins. 1974. Regulation of adenosine $3^{\prime}: 5^{\prime}$-monophosphate content in human astrocytoma cells by adenosine and the adenine nucleotides. J. Biol. Chem. 249: 5296-5303. 